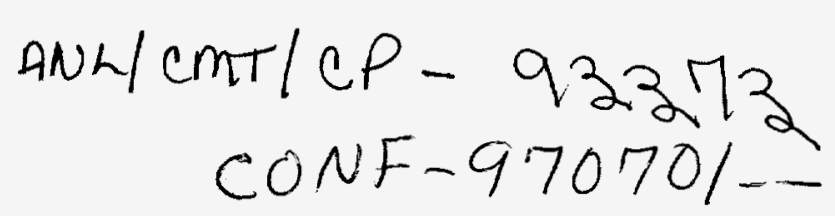

\title{
A COMPARISON OF TWO ALUMINIZING METHODS FOR CORROSION PROTECTION IN THE WET SEAL OF MOLTEN CARBONATE FUEL CELLS*
}

\author{
Ira Bloom, J. Ernesto Indacochea, and Michael Krumpelt \\ Electrochemical Technology Program \\ Chemical Technology Division \\ Argonne National Laboratory \\ 9700 S. Cass Avenue \\ Argonne, Illinois 60439 \\ Phone: (630) 252-4516 Fax: (630) 252-4176
}

Thomas G. Benjamin

MC-Power Corporation

8040 S. Madison

Burr Ridge, Illinois 60521

RECEIVED

JUN 204997

OSTI

Phone: (630) 986-8040 Fax: (630) 986-8153

Paper prepared for the 32nd Intersociety Energy Conversion Engineering Conference Honolulu, Hawaii

July 27 - August 1, 1997

\section{DISTRIDUTION OF THIS DOCUMENT IS UNLMATED}

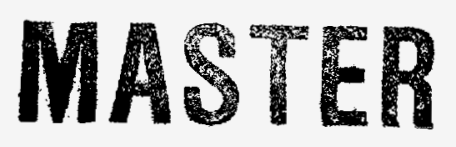

$$
\begin{aligned}
& \text { The submitted manuscript has been created by the } \\
& \text { University of Chicago as Operator of Argonne } \\
& \text { National Laboratory ("Argonne") under Contract No. } \\
& \text { W-31-109-ENG-38 with the U.S. Department of } \\
& \text { Energy. The U.S. Government retains for itself, and } \\
& \text { others acting on its behalf, a paid-up, nonexclusive, } \\
& \text { irrevocable worldwide license in said article to } \\
& \text { reproduce, prepare derivative works, distribute copies } \\
& \text { to the public, and perform publicly and display } \\
& \text { publicly, by or on behalf of the Government. }
\end{aligned}
$$

*Work supported by the U.S. Department of Energy, Federal Energy Technolgy Center, under Contract W-31-109-ENG-38. 


\section{DISCLAIMER}

This report was prepared as an account of work sponsored by an agency of the United States Government. Neither the United States Government nor any agency thereof, nor any of their employees, make any warranty, express or implied, or assumes any legal liability or responsibility for the accuracy, completeness, or usefulness of any information, apparatus, product, or process disclosed, or represents that its use would not infringe privately owned rights. Reference herein to any specific commercial product, process, or service by trade name, trademark, manufacturer, or otherwise does not necessarily constitute or imply its endorsement, recommendation, or favoring by the United States Government or any agency thereof. The views and opinions of authors expressed herein do not necessarily state or reflect those of the United States Government or any agency thereof. 


\section{DISCLAIMIER}

Portions of this docoment may be illegible in electronic image produets. Images are produced from the best available original docement. 
During testing, the cell potential was maintained at 800 $\mathrm{mV}$ at $650^{\circ} \mathrm{C}$ for $500 \mathrm{~h}$. After the test, the samples were cleaned with dilute acetic acid and mounted for metallography.

Scanning-electron microscopy (SEM) analyses were performed to characterize the microstructure of each coupon. Energy dispersive analysis of X-rays (EDX) was used to assess the interdiffusion of the steel and aluminizing layers. The compositions were calculated from the observed ratio of the metals. X-ray diffraction (XRD) was used to identify the phases present on, and immediately below, the surface of the sample.

\section{RESULTS AND DISCUSSION}

\section{As-received Coupons}

A serrated microstructure was seen at the Al/SS interface in both types of samples (see Fig. 2). The thickness of the interfacial layer was about $1.5-3.0 \mu \mathrm{m}$.

The microstructure of set 1 samples consisted of a duplex structure on the SS base metal. Analyses by XRD showed that the outer layer consisted of $\mathrm{Al}$ and the inner layer consisted of iron aluminides. The EDX and XRD analyses showed that the bulk of the inner layer consisted of $\mathrm{Fe}_{2} \mathrm{Al}_{5} ; \mathrm{FeAl}_{3}$ was found near the Al/SS interface (Fig. 3).

The microstructure of set 2 samples consisted of a single layer of iton aluminides. The EDX analysis showed that the bulk of the layer consisted of $\mathrm{FeAl}_{3} ; \mathrm{FeAl}_{2}$ was present at the Al/SS interface. The different phase distribution between sets 1 and 2 is due to the differences in the aluminizing process.

During the aluminizing process, $\mathrm{Cr}$ and $\mathrm{Ni}$ also diffuse into the aluminizing layer. ${ }^{10}$ As expected, the concentrations of these species are greatest at the interface. For example, the concentrations are 8 and $10 \mathrm{wt} \%$ for $\mathrm{Ni}$ and $\mathrm{Cr}$, respectively, in the set 2 samples. No aluminum was found in the SS substrate.

\section{In-cell Test}

After $500 \mathrm{~h}$ of in-cell testing, different intermetallic phases were seen metallographically between the two sets of coupons. No microstructural differences were seen between the samples from the fuel gas inlet and gas outlet. The EDX analyses of set 1 coupons revealed the following intermetallic phases: $\mathrm{FeAl}, \mathrm{FeAl}_{2}, \mathrm{Fe}_{3} \mathrm{Al}$, and $\mathrm{Fe}_{2} \mathrm{Al}_{5}$ (see Fig. 4). Similar analyses of set 2 coupons revealed only $\mathrm{FeAl}$ and $\mathrm{FeAl}_{2}$.

The set 1 samples did not show significant corrosion after the test. The thickness of the aluminum layer remained unchanged and no noticeable corrosion scale developed. A closer examination of these samples showed a rough surface (Fig. 4). The surface texture was first thought to be from the aluminizing process. In the thermal-spray process, aluminum droplets strike the surface of the steel, producing a rough texture due to droplet splattering. Samples of set 2 showed a similar phenomenon, that is, a rough texture on the outer surface of the aluminizing layer (Figs. $5 \mathrm{a}$ and $5 \mathrm{~b}$ ). However, the slurry-coating process produces a smooth surface; thus, the observed texture cannot be from the set 2 aluminizing process. The texture of the set 2 sample goes farther into the deposit than that of the set 1 sample: it penetrates a distance of $15-25 \mu \mathrm{m}$.

The EDX results from the regions near the electrolyte of set $I$ and set 2 samples show that the atomic ratios of the metals are different. The ratio of $\mathrm{Fe}: \mathrm{Al}: \mathrm{Cr}: \mathrm{Ni}$ is $2.3: 10: 1: 1$ for set 1 and 3.5:5:1:1 for set 2 . The high Fe concentration in set 2 is expected because its bulk composition began the experiment as $\mathrm{FeAl}_{3}$. The high $\mathrm{Fe}$ concentration in the aluminizing layer may be the cause of the greater corrosion damage in set 2 coupons.

The phase distributions are different in the two types of coupons, as shown by XRD (see Figs. $6 \mathrm{a}$ and $6 \mathrm{~b}$ for sets 1 and 2 , respectively). The phases present in both samples are $\alpha-$ and $\gamma$ $\mathrm{LiAlO}_{2}, \mathrm{Cr}_{4} \mathrm{Al}_{9}, \mathrm{Fe}_{2} \mathrm{Al}_{5}, \mathrm{FeAl}$ or $\mathrm{Fe}_{3} \mathrm{Al}$, ${ }^{1}$ and an unknown phase. The ratio of the phases was calculated using the intensity of the diffraction peaks at $2 \theta=18.7,22.5,43.2,42.8$, and $44.1^{\circ}$, respectively. These ratios are given in Table 1 and indicate which species provide corrosion protection.

Table 1. Intensity Ratios of Species in the Set 1 and Set 2 Aluminizing Layers

\begin{tabular}{|l|c|c|c|}
\hline & \multicolumn{3}{|c|}{ Intensity Ratio } \\
\hline & $\alpha-\gamma \gamma-\mathrm{LiAlO}_{2}$ & $\mathrm{Fe}_{2} \mathrm{Al}_{5}: \mathrm{Cr}_{4} \mathrm{Al}_{9}$ & $\mathrm{FeAl}^{\mathrm{a}}: \mathrm{Cr}_{4} \mathrm{Al}_{9}$ \\
\hline Set 1 & 0.7 & 0.6 & 0.3 \\
\hline Set 2 & 2.0 & 2.7 & 14.7 \\
\hline
\end{tabular}

${ }^{\mathrm{a}} \mathrm{FeAl}$ and/or $\mathrm{Fe}_{3} \mathrm{Al}$.

Initially, the electrolyte tile consisted of $\gamma-\mathrm{LiAlO}_{2}+$ $(\mathrm{Li}, \mathrm{K})_{2} \mathrm{CO}_{3}$. The greater amount of $\alpha-\mathrm{LiAlO}_{2}$ on set 2 samples as compared to that on set 1 samples indicates greater oxidation of the aluminizing layer. However, a corresponding Fe-containing product from the reaction was not observed (e.g., $\mathrm{LiFeO}_{2}$ ). An explanation is that the Fe-containing product spalled off or came off during the acetic acid cleaning.

We found that the lithium aluminates are easily removed by soaking the sample in $50 \%$ nitric acid for about 1 minute (XRD evidence). Thus, the lithium aluminates are present on the surface and are not tenacious; the other peaks present in the XRD before the washing are still there afterwards.

The high concentration of Fe-containing phases present in set 2 is more important than the presence of lithium aluminates. As stated earlier, the bulk of set 2 coating material initially consisted of $\mathrm{FeAl}_{3}$. The distribution of phases shown in Table 1 indicates the equilibrium composition of $\mathrm{FeAl}_{3}$ and Type $310 \mathrm{~S} \mathrm{SS}$. Since the $\mathrm{FeAl} / \mathrm{FeAl}_{3}$-type materials predominate, they may be responsible for the corrosion behavior of the set 2 material. Separate experiments on the corrosion behavior of the $\mathrm{Fe}$ - and $\mathrm{Cr}$-containing phases given in Table 1 are necessary to determine which is the most corrosion resistant (i.e., protective) coating material

\section{CONCLUSIONS}

Examination of set 1 and 2 samples reveals an initially serrated interface that consists of iron aluminides. Resolvable, changes in the bulk microstructure occurred after about $500 \mathrm{~h}$. No corrosion layer growth was observed, but some of the aluminum deposit formed $\mathrm{Fe}-\mathrm{Al}$ phases in both coupons.

\footnotetext{
'The XRD patterns of $\mathrm{FeAl}$ and $\mathrm{Fe}_{3} \mathrm{Al}$ are too similiar to be differentiated here. The exact patterns are found on JCPDS Card Numbers 33-0020 and 45-1203, respectively.
} 


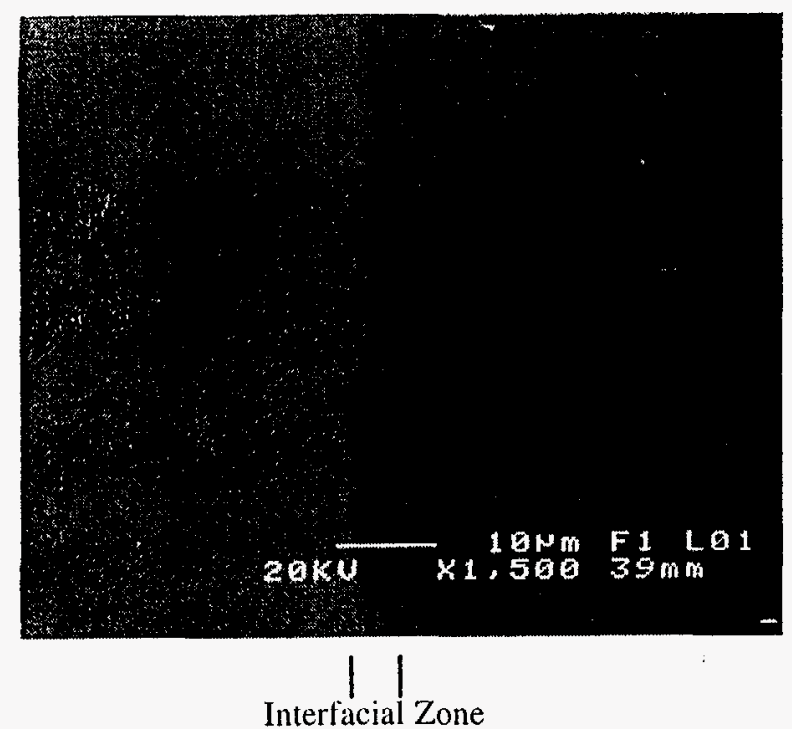

Fig. 2. Typical serrated layer found at the Al/SS

interface of all as-received samples. This micrograph is from a set 2 coupon betore exposure.

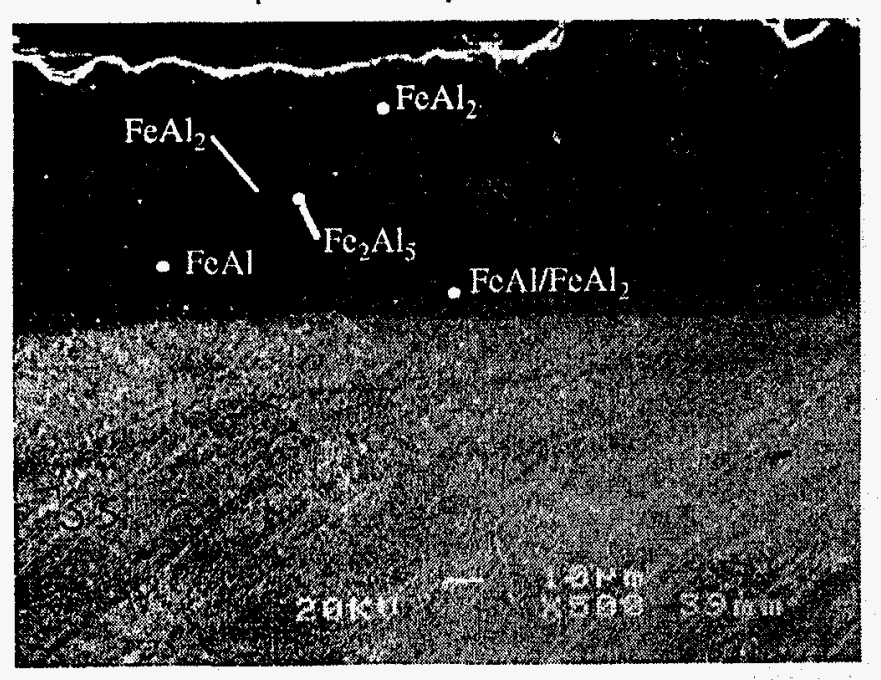

Fig. 4. Micrograph of aluminizing layer on a set 1 coupon after $500 \mathrm{~h}$ of in-cell test. Air was the cover gas; sample was placed in the fuel exhaust section of wet seal.

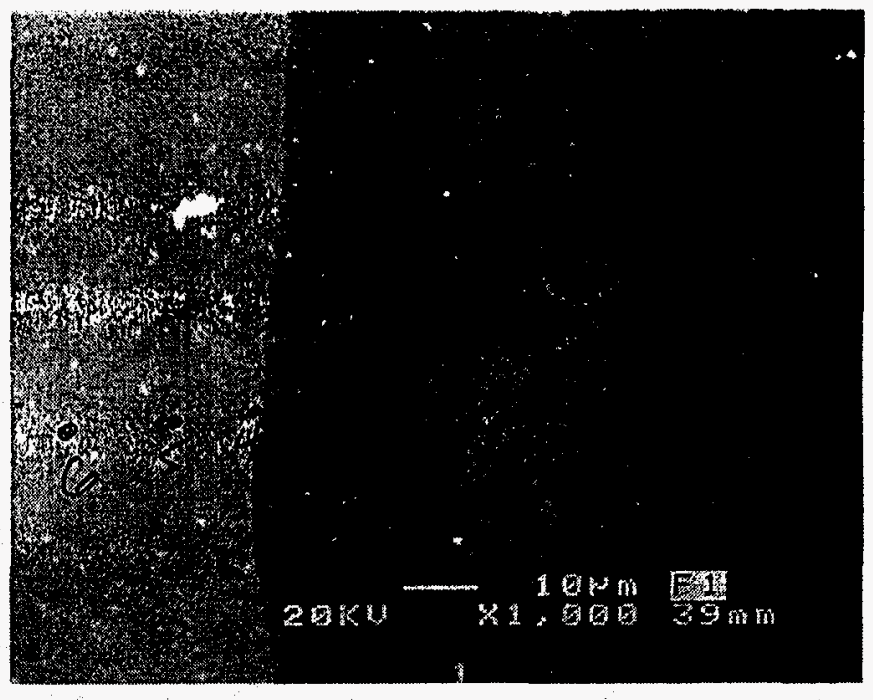

Fig. 3. Micrograph of Al/SS interface of a set 1 coupon before in-cell test showing the locations of the spot analyses.

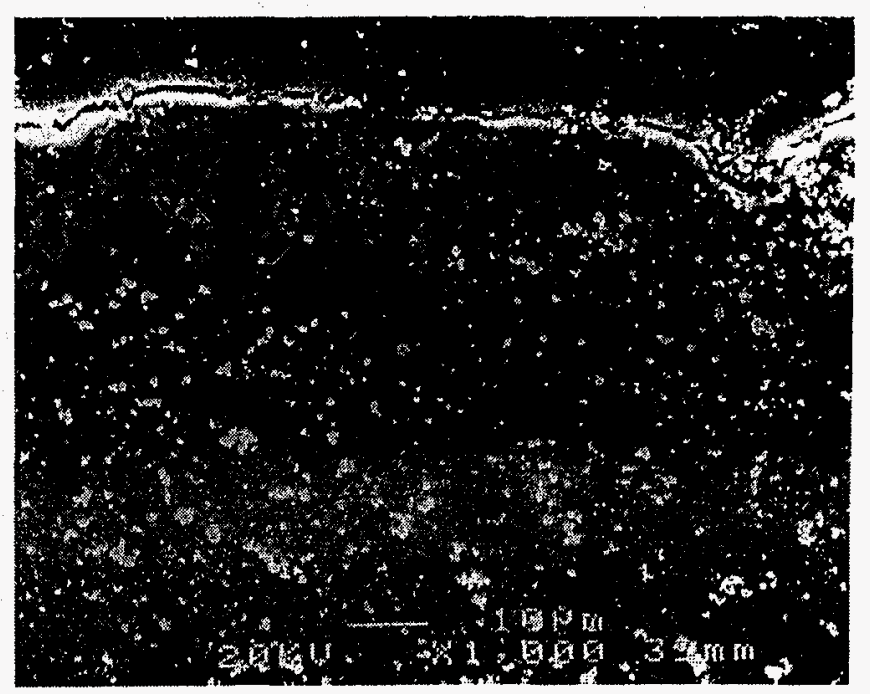

Fig. 5a. Micrograph of aluminizing layer on a set 2 coupon after $500 \mathrm{~h}$ of in-cell test. Air was the cover gas; sample was placed in the anode exhaust section of the wet seal. 